\title{
ACETYLCHOLINESTERASE AND BUTYRYLCHOLINESTERASE - IMPORTANT ENZYMES OF HUMAN BODY
}

\author{
Jiř̌ Patočka ${ }^{1,2}$, Kamil Kuča ${ }^{1}$, Daniel Jun ${ }^{1}$ \\ Purkyně Military Medical Academy in Hradec Králové, Czech Republic: Department of Toxicology ${ }^{1}$; University of South \\ Bohemia, Faculty of Health and Social Studies, České Budějovice, Czech Republic: Department of Radiology and \\ Toxicology ${ }^{2}$
}

Summary: The serine hydrolases and proteases are a ubiquitous group of enzymes that is fundamental to many critical lifefunctions. Human tissues have two distinct cholinesterase activities: acetylcholinesterase and butyrylcholinesterase. Acetylcholinesterase functions in the transmission of nerve impulses, whereas the physiological function of butyrylcholinesterase remains unknown. Acetylcholinesterase is one of the crucial enzymes in the central and peripheral nerve system. Organophosphates and carbamates are potent inhibitors of serine hydrolases and well suited probes for investigating the chemical reaction mechanism of the inhibition. Understanding the enzyme's chemistry is essential in preventing and/or treating organophosphate and carbamate poisoning as well as designing new medicaments for cholinergic-related diseases like as Alzheimer's disease.

Key words: Acetylcholine; Acetylcholinesterase; Butyrylcholinesterase; Molecular forms; Cholinergic receptor; Organophosphates; Nerve agents; Carbamates; Reactivator; Oximes; Inhibition; Reactivation; Alzheimer's disease; Cholinolytics; Cholinomimetics

\section{Introduction}

Acetylcholinesterase $(\mathrm{AChE})$ is one of the most crucial enzymes for nerve response and function. AChE catalyzes the hydrolysis of acylcholine esters with a relative specificity for acetylcholine. Acetylcholine is a common neurotransmitter found in the central and peripheral nervous system. When acetylcholine is released from an axon terminal, it moves across the synaptic cleft to bind to a receptor on the other side of the synapse. In the peripheral nervous system, acetylcholine is located at the „neuromuscular junction“ where it acts to control muscular contraction. Acetylcholine is also used in the autonomic nervous system. The intracellular effects of acetylcholine are mediated by the activation of nicotinic and muscarinic acetylcholine receptors (AChRs). AChE terminates transmission of neuronal impulses by rapid hydrolysis of acetylcholine (11).

\section{Acetylcholine receptors}

AChRs in the mammalian CNS can be divided into muscarinic and nicotinic subtypes based on the ability of the natural alkaloids, muscarine and nicotine, to mimic the effects of acetylcholine as a neurotransmitter (81). AChRs also mediate synaptic transmission at the neuromuscular junction. The channel-linked AChR that mediates rapid, excitatory actions of acetylcholine is called nicotinic AChR ( $\mathrm{AAChR}$ ) because it can be activated by nicotine. The nonchannel linked AChR that mediates the slow actions of acetylcholine, which can be either inhibitory or excitatory, is called muscarinic AChR (mAChR) because it can be activated by muscarine.

\subsection{Nicotinic AChRs}

The nAChRs arguably has the longest history of experimental study of any receptor, and is the prototype of ligandgated ion channel. The nAChRs mediate the passage of potassium and sodium ions across synaptic membranes. Two classes of receptors exist: the neuromuscular nAChRs, which mediate signals between nerve and muscle cells, and the neuronal nAChRs, which are found throughout the nervous system. Until recently, studies of the neuropsychopharmacological effects of acetylcholine have focused on mAChRs, while nAChRs have been evaluated primarily for their role in mediating neuromuscular and autonomic transmission. However, over the last decade, this trend has changed following preclinical and clinical studies indicating that neuronal nAChRs may have a substantial role in mediating antinociception, cognitive performance, modulating 
affect, and enhancing the release of other neurotransmitters.

These receptors comprise five homologous subunits, arranged either as a homopentameric or a pseudo-pentameric structure, depending on the types of subunits present (64). The small molecule acetylcholine ( $\mathrm{ACh}$ ), the activating ligand of these receptors, binds to two sites in a receptor, inducing a conformational change that is transmitted allosterically from the binding site through the subunits. The channels open as a result, permitting potassium and/or sodium ion passage across the membrane.

\subsubsection{Classification of $n A C h R s$}

The muscle $\mathrm{nAChR}$ is a ligand-gated ion channel (LGIC) receptor composed of 5 subunits: two alpha 1 subunits, and one each of beta ${ }_{1}$, delta and gamma (or epsilon, depending on the stage of development). Several genes have been identified in rat and chick neural or sensory tissue that encode for neuronal nAChR subunits that are distinct from those in the muscle $\mathrm{nAChR}$, providing for a multitude of potential subtypes of neuronal nAChRs. The wide distribution of the some of these transcripts in mammalian brain indicates that neuronal nAChRs represent a major neurotransmitter receptor superfamily related to other LGICs including serotonin $\left(5 \mathrm{HT}_{3}\right), \mathrm{GABA}_{\mathrm{A}}$, N-methylD-aspartate (NMDA), and glycine.

Receptor nomenclature in the nAChR area has been derived from classical pharmacology approaches. Paton and Zaimis (1952) showed that the antagonist decamethonium (C10) was more effective than hexamethonium (C6) in blocking muscle nAChRs, whereas $\mathrm{C} 6$ was effective in autonomic ganglia. This led to the description of ' $\mathrm{C} 10$ ' (muscle) and 'C6' (neuronal) receptors (19). Muscle nAChRs are selectively activated by phenyltrimethylammonium salts and are pseudo-irreversibly blocked by alpha-bungarotoxin (alpha-BgT), toxic peptide from the venom of snake Bungarus multicinctus. Ganglionic nAChRs are preferentially activated by 1,1-dimethyl-4-phenylpiperazinium (DMPP), competitively blocked by trimethaphan, and are resistant to snake alpha-toxins, yet sensitive to neuronal bungarotoxin (n-BgT: also known as kappa-BgT, alpha-BgT 3.1, or toxin F) (101).

Brain nAChRs are a class of LGIC composed of alpha and beta subunits with specific structural, functional and pharmacological properties. They participate in the physiological and behavioural effects of acetylcholine and mediate responses to nicotine. They are associated with numerous transmitter systems and their expression is altered during development and ageing as well as in diseases such as autism, schizophrenia, Alzheimer's disease, Parkinson's disease and Lewy body dementia. Nicotinic receptors containing a number of different subunits are highly expressed during early human development (27).

In mammalian brain, two major neuronal nAChRs subclasses can be delineated using radioligand binding (93): those that bind a-BgT with high affinity (a-BgT-sensitive
nAChRs, with $\mathrm{Kd} \sim 0.5 \mathrm{nM}$ using $\left.\left[{ }^{125} \mathrm{I}\right] \mathrm{a}-\mathrm{BgT}\right)$ and those that do not (a-BgT-insensitive nAChRs). a-BgT-sensitive $n A C h R s$ have low affinity for (-)-nicotine, whereas a-BgT-insensitive nAChRs have high affinity $(\mathrm{Kd}=0.5-5 \mathrm{nM})$ for $\left[{ }^{3} \mathrm{H}\right](-)$-nicotine, $\left[{ }^{3} \mathrm{H}\right] \mathrm{ACh},\left[{ }^{3} \mathrm{H}\right]$ methylcarbamylcholine (MCC), and $\left[{ }^{3} \mathrm{H}\right]$ cytisine). All four of these $\left[{ }^{3} \mathrm{H}\right]$ agonist ligands are thought to interact with the same acetylcholine binding sites on the nAChR (82).

\subsubsection{Molecular diversity of $n A C h R s$}

The nAChRs are encoded by a family of related but distinct genes that share a common origin and have a long phylogenetic history. The current number of neuronal nAChR subunits in mammals is eleven (alpha2-alpha7, alpha9, alpha10, beta2-beta4), with an additional subunit, alpha8, identified in avian species. Nine subunits (alpha2-alpha10) code for a subunits based on the presence of adjacent cysteine residues in the predicted protein sequences, in a region homologous to the putative agonist binding site of the muscle a subunit (alpha1) while three are referred to as non-alpha or beta subunits (beta2-beta4). Each of the $\mathrm{nAChR}$ subunits displays a characteristic phenotype of structural features extending from the $\mathrm{N}$-terminus to the $\mathrm{C}$ terminus: 1$)$ a large ( 200 amino acids) $\mathrm{N}$-terminal hydrophilic domain containing the multiple loops of the neurotransmitter binding site; 2) the highly variable C-terminal hydrophilic domain that faces the cytoplasm, where it can be phosphorylated; and 3) a set of four closely spaced transmembrane domains-termed M1-M4-immediately following the large extracellular domain. The M2 domain is believed to form the wall of the ion channel. The amino acid sequences of the neuronal $\mathrm{nAChR}$ genes except alpha7 and alpha8 are between $40-60 \%$ similar (22). The alpha7 and alpha 8 genes share approximately $70 \%$ similarity, with a much lower level $(<30 \%)$ of similarity to the other $\mathrm{nAChR}$ genes. The alpha9 subunit is the most unique of the alpha-subunits displaying less than $50 \%$ similarity to alpha2-alpha8 (67). Comparison of the nAChR sequences also reveals that several pairs of subunits display homologies that are instructive in considering their function. For example the beta 2 and beta 4 are highly homologous, consistent with their ability to substitute for one another in forming functional channels when paired with alpha2, alpha3, or alpha4 subunits.

Some human brain disorders believed to be associated with abnormal brain maturation involve deficits in both alpha4beta 2 , in the case of autism, and alpha 7 possibly in addition to alpha4beta 2 nAChRs in the case of schizophrenia. In ageing and age-related neurodegenerative disorders nAChR deficits are predominantly associated with alpha4containing receptors, although some studies also indicate the involvement of alpha3 and alpha7 subunits (27).

\subsubsection{Topology of ligand binding sites on $n A C h R$}

The nAChR presents two very well differentiated domains for ligand binding that account for different choli- 
nergic properties. In the hydrophilic extracellular region of both alpha subunits there exist the binding sites for agonists such as the neurotransmitter acetylcholine and for competitive antagonists such as d-tubocurarine. Agonists trigger the channel opening upon binding while competitive antagonists compete for the former ones and inhibit its pharmacological action. Identification of all residues involved in recognition and binding of agonist and competitive antagonists is a primary objective in order to understand which structural components are related to the physiological function of the AChR. These sites are mainly located on both alpha subunits in a pocket approximately 30-35 A above the surface membrane. Since both alpha subunits are sequentially identical, the observed high and low affinity for agonists on the receptor is conditioned by the interaction of the alpha subunit with the delta or the gamma chain, respectively.

The principal component for the agonist/competitive antagonist binding sites involves several aromatic residues, in addition to the cysteine pair at 192-193, in three loopsforming binding domains (loops A-C). Other residues such as the negatively changed aspartates and glutamates (loop D), Thr or Tyr (loop E), and Trp (loop F) from non-alpha subunits were also found to form the complementary component of the agonist/competitive antagonist binding sites. Neurotoxins such as alpha-, kappa-bungarotoxin and several alpha-conotoxins seem to partially overlap with the agonist/competitive antagonist binding sites at multiple point of contacts. The alpha subunits also carry the binding site for certain acetylcholinesterase inhibitors such as eserine and for the neurotransmitter 5-hydroxytryptamine which activate the receptor without interacting with the classical agonist binding sites. The link between specific subunits by means of the binding of acetylcholine molecules might play a pivotal role in the relative shift among receptor subunits. This conformational change would allow for the opening of the intrinsic receptor cation channel transducting the external chemical signal elicited by the agonist into membrane depolarisation. The ion flux activity can be inhibited by non-competitive inhibitors. For this kind of drugs, a population of low-affinity binding sites has been found at the lipid-protein interface of the AChR. In addition, several high-affinity binding sites have been found to be located at different rings on the M2 transmembrane domain, namely luminal binding sites. In this regard, the serine ring is the locus for exogenous non-competitive inhibitors such as chlorpromazine, triphenyl methyl phosphonium, the local anaesthetic QX-222 or phencyclidine (6).

\subsection{Muscarinic AChRs}

The mAChRs were first defined on the operational basis of selective agonism by muscarine and antagonism by atropine (86). The mAChRs are present in neurons of the central and peripheral nervous system, cardiac and smooth muscle and various exocrine glands (51). There are $5 \mathrm{sub}$ types (M1-M5) of the receptor that have a tissue specific pattern of expression (110). The M2 receptor is localized primarily in cardiac tissue and is also expressed at low levels in the hippocampus, cortex, striatum, thalamus, basal forebrain, brainstem, lung, vas deferens and uterus. The acetylcholine receptor channel is placed at the junction between the neuronal synapse and the muscle fiber. If the synapse becomes excited, the acetylcholine filled vesicles secrete their neurotransmitter into the synaptic cleft. This neurotransmitter opens the AChR channels resulting in an ionic current through the channels. The currents in turn excites the muscle fibers which then contract.

In the periphery, mAChRs mediate smooth muscle contraction, glandular secretion, and modulation of cardiac rate and force. In the CNS, mAChRs mediate motor control, temperature regulation, cardiovascular regulation and memory (96).

\subsubsection{Classification of $m A C h R s$}

Five intronless genes encode all the mAChRs in vertebrates. The coding genes are fairly similar across species and exhibit sequence and structural homologies. Structurally, the muscarinic receptors are glycoproteins that display seven transmembrane pass domains similar to the G-protein-coupled receptor superfamily (96). The sequence homology also holds between muscarinic receptor subtypes across species, to the extent that they are classified as species homologues, i.e. when greater than $90 \%$ of the amino

Tab. 1: Muscarinic acetylcholine receptor subtypes, G protein coupling, transductional mechanism and functional response.

\begin{tabular}{|l|l|l|l|l|l|}
\hline & M1 & M2 & M3 & M4 & M5 \\
\hline $\begin{array}{l}\text { Prefered } \\
\text { G-Protein }\end{array}$ & Gq/11 & Gi/o & Gq/11 & Gi/o & Gq/11 \\
\hline $\begin{array}{l}\text { The 2nd } \\
\text { Messengers }\end{array}$ & $\begin{array}{l}\text { PLC } \\
\mathrm{IP}_{3} / \text { DAG } \\
\mathrm{Ca}^{2+} / \mathrm{PKC}\end{array}$ & $\mathrm{AC}(-)$ & $\begin{array}{l}\mathrm{PLC} \mathrm{IP}_{3} / \mathrm{DAG} \\
\mathrm{Ca}^{2+} \mathrm{PKC}\end{array}$ & $\mathrm{AC}(-)$ & $\begin{array}{l}\text { PLC } \\
\mathrm{IP}_{3} / \mathrm{DAG} \\
\mathrm{Ca}^{2+} / \mathrm{PKC}^{-}\end{array}$ \\
\hline $\begin{array}{l}\text { Functional } \\
\text { Response }\end{array}$ & $\begin{array}{l}\text { M-current } \\
\text { inhibition }\end{array}$ & $\begin{array}{l}\mathrm{K}^{+} \text {channel activation, } \mathrm{Ca}^{2+} \text { channel } \\
\text { inhibition, decreases heart rate and } \\
\text { force, decreased neurotransmitter } \\
\text { release (presynaptic) }\end{array}$ & $\begin{array}{l}\text { Smooth muscle contraction, } \\
\text { gland secretion, decreased } \\
\text { neurotransmitter release } \\
\text { (presynaptic) }\end{array}$ & $\begin{array}{l}\mathrm{Ca}^{2+} \\
\text { channel } \\
\text { inhibition }\end{array}$ & $\begin{array}{l}\mathrm{n} / \mathrm{a} \\
\end{array}$ \\
\hline
\end{tabular}


acid sequence is identical between receptors from different species. It is known that the minor sequence differences between species have a major impact on the pharmacological profiles but in the case of mAChR family, small sequence differences between mammalian species do not alter the pharmacological profiles and the order of potency mAChR agonists (42). In addition to being activated in the presence of agonists, $\mathrm{mAChRs}$ can interact with G-proteins in the absence of agonist, leading to activation of the G-protein pathway. This type of activation in the absence of a ligand is called constitutive activity (62). The summary of the major properties of mAChR subtypes is shown in Tab. 1.

\section{Cholinesterases}

Cholinesterase (ChE) is a generic term used for a family of related enzymes that hydrolyze choline esters at a faster rate than other esters under optimal conditions. These are serine hydrolases that belongs to the esterase family within higher eukaryotes. This family acts on different types of carboxylic esters (2). There are two types of $\mathrm{ChE}$ in the human body, with several variations and a confusing set of names. One type of $\mathrm{ChE}$ is acetylcholinesterase (AChE) (or acetylcholine acetyl-hydrolase, EC 3.1.1.7) also known as true, specific, genuine or type $1 \mathrm{ChE}$. This enzyme is found in erythrocytes, nerve endings, lungs, spleen and in the all compartments of brain. This enzyme is a membrane-bound glycoprotein and exists in several molecular forms. The other subgroup, butyrylcholinesterase (BuChE) (or acylcholine acyl-hydrolase, EC 3.1.1.8) also known as plasma, serum, benzoyl, false, butyryl, nonspecific, or type II ChE. $\mathrm{BuChE}$ exists in plasma and has more than eleven isoenzyme variants. BuChE is also present in liver, smooth muscle, intestines, pancreas, heart and white matter of brain (70).

\subsection{Butyrylcholinesterase}

The enzyme is found in mammalian blood plasma, liver, pancreas, intestinal mucosa and the white matter of the central nervous system. It is sometimes referred to as serum $\mathrm{ChE}$ as opposed to red cell cholinesterase i.e. AChE. It hydrolyzes butyrylcholine 4 times more rapidly than acetylcholine. The BuChE does not hydrolyze D- $\beta$-methyl acetylcholine whereas $\mathrm{AChE}$ does. The enzyme is more active with butyryl and propionyl choline than with acetyl choline (68).

In humans, BuChE is synthesized in many tissues, including the liver, lungs, heart and brain. For a long time the physiological function of $\mathrm{BuChE}$ was vague. Nowadays the roles for BuChE have been suggested, for example, in lipoprotein metabolism (60), myelin maintenance (41), cellular adhesion and neurogenesis (61), as a scavenger of toxic molecules (100) and in the processing of the amyloid precursor protein (9). In human brain, the enzyme is found in neurones (29), glia (115) and in the plaques and tangles of Alzheimer' disease (AD) (47). Furthermore, the activity of
$\mathrm{BuChE}$ in the brain increases with age and is raised in AD (87). The BuChE plays important role in metabolism of some compounds. It hydrolyses also non-choline esters e.g. local anesthetics procaine, amethocaine or bupivacaine (45), suxamethonium (77), cocaine (20) and some other compounds, such as aspirin (69). The ability of BuChE to hydrolyze cocaine can be very important. Exogenously administered $\mathrm{BuChE}$ can accelerate cocaine metabolism in such a way as to potentially lessen the behavioral and toxic effects of cocaine. Therefore, BuChE may be useful as a treatment for cocaine addiction and toxicity. Because BuChE is alike as AChE inhibited by organophosphate compounds, the reduction in plasma activity is a means of monitoring exposure of individuals to organophosphates (98). The pretreatment with purified exogenous human or equine serum $\mathrm{BuChE}$ is tested as a new therapeutic agent for protection against nerve agents and antidote against organophosphate lethality, without producing the adverse side effects associated with conventional treatments $(8,73)$.

\subsubsection{BuChE genotypes}

Several genetic variants of human $\mathrm{BuChE}$ are reportedly associated with prolonged apnoea in patients given the muscle relaxant drug succinylcholine (16). An estimation of the serum BuChE activity, dibucaine number (DN) and fluoride number ( $\mathrm{FN}$ ) have, in the past, been sufficient to identify most of the known BuChE phenotypes associated with succinylcholine sensitivity (37). However, several additional BuChE variants have been discovered in the last 10-20 years, which complicates the phenotyping of individuals. The molecular basis for a number of these variants has been reported, and it has become clear that multiple mutations within a single BuChE gene are not rare (12). The gene for BuChE is at chromosome 3q26.1-q26.2 and has several variants, such as the atypical (dibucaine-resistant), fluoride-1 and -2 (fluoride-resistant), and silent alleles, as well as the $\mathrm{K}, \mathrm{J}$ and $\mathrm{H}$ variants, which result in reduced activity of $\operatorname{BuChE}(3,46)$. The atypical allele, well known for the associated succinylcholine hypersensitivity, is found in approximately $4 \%$ of Caucasians. The various silent alleles are associated with no esteratic activity and are very rare (4). The most common coding region polymorphism is the $\mathrm{K}$ variant, found in about $33 \%$ of Caucasians and Orientals, i.e. with an allelic frequency of $18 \%$. It has a DNA point mutation from guanine to adenine at nucleotide 1615 in exon 4, changing alanine 539 to threonine, near the carboxy terminus of the 574 amino acid protein. The $\mathrm{K}$ variant of BuChE results in $30 \%$ less plasma activity, due to fewer circulating enzyme molecules (94). The mutation, however, does not affect the esteratic activity, protein turnover or tetramer formation. Of these polymorphisms, only the $\mathrm{K}$ variant has been seriously studied as a gene associated with the development of $\operatorname{AD}(63,74)$. The atypical allele has also been investigated. However, no AD association was found among the six atypical carriers. Genetic variation is one of several factors determining the level and 
quality of plasma cholinesterase activity and it is very possible that individual differences can have till this time unexpected connections ${ }^{1}$.

\subsubsection{Molecular structure of BuChE}

The molecule of BuChE contains 574 amino acids per subunit and nine carbohydrate chains attached to 9 asparagines. The four subunits of $\mathrm{ChE}$ appear to be identical and create tetramer molecule of $\mathrm{BuChE}$. The active site serine is the 198th residue from the amino terminus. The sequence of human serum $\mathrm{ChE}$ is $53.8 \%$ identical with the sequence of acetylcholinesterase from Torpedo californica and 28\% identical with the carboxyl-terminal portion of bovine thyroglobulin (66). Human serum ChE contains 8 half-cystines in each subunit of 574 amino acids. Six of these form three internal disulfide bridges: between Cys65-Cys92, Cys252Cys263, and Cys400-Cys519. The disulfide bridges in human BuChE have exactly the same location as in Torpedo californica acetylcholinesterase. There is one potential free sulfhydryl in human ChE at Cys66, but this sulfhydryl could not be alkylated. Comparison of human $\mathrm{ChE}$, and Torpedo and Drosophila acetylcholinesterases to the serine proteases suggests that the cholinesterases constitute a separate family of serine esterases, distinct from the trypsin family and from subtilisin (65).

The $\mathrm{BuChE}$ gene is at least $73 \mathrm{~kb}$ long, includes 1,722 basepairs of the coding sequence corresponding to the protein found circulating in human serum and contains four exons. Exon 1 contains untranslated sequences and two potential translation initiation sites at codons-69 and 47. Exon 2 ( 1525 basepairs) contains $83 \%$ of the coding sequence for the mature protein, including the N-terminal and the activesite serine, and a third possible translation initiation at codon-28. Exon 3 is 167 nucleotides long. Exon 4 (604 basepairs) codes for the C-terminus of the protein and the 3 ' untranslated region where two polyadenylation signals were identified. Intron 1 is $6.5 \mathrm{~kb}$ long, and the minimal sizes of introns 2 and 3 are estimated to be $32 \mathrm{~kb}$ each. Southern blot analysis of total human genomic DNA is in complete agreement with the gene structure established by restriction endonuclease mapping of the genomic clones: this strongly suggests that the $\mathrm{BuChE}$ gene is present in a single copy (7).

\subsection{Acetylcholinesterase}

Acetylcholinesterase $(\mathrm{AChE})$ is likewise as $\mathrm{BuChE}$ a serine hydrolase that belongs to the esterase family within higher eukaryotes. This family acts on different types of carboxylic esters. Acetylcholinesterase's biological role is the termination of impulse transmissions at cholinergic sy- napses within the nervous system by rapid hydrolysis of the neurotransmitter, acetylcholine (99).

\subsubsection{Molecular structure of AChE}

The monomer of $\mathrm{AChE}$ with a molecular weight around 60,000 is an ellipsoidal molecule approximately $45 \times 60 \mathrm{x}$ $65 \AA$, which consists of a 12 stranded central mixed beta sheet surrounded by 14 alpha helices (106). Studies have indicated several major domains within the protein: a catalytic active site composed of two subsites, the aromatic gorge in which the catalytic active site lies, and a peripheral anionic site, distinct from the catalytic active site, which plays a role in the confirmation of the residues within the aromatic gorge and active site.

\subsubsection{Active site of AChE}

The active site is composed of two subsites: the esteratic subsite which contains the catalytic triad, and the anionic subsite that accommodates the positive quaternary compartment of acetylcholine. The esteratic subsite contains the catalytic machinery of the enzyme: a catalytic triad of Ser 200, His 440, and Glu 327. This catalytic triad is similar to other serine proteases, except that this triad is the first to show Glu as the third member as opposed to Asp. The anionic subsite is defined by Trp 84, Phe 330, and Phe 331. Its role is to orient the charged part of the substrate that enters the active center. This role is the main function of the Trp residue (106). The recent rendition of the x-ray structure for AChE places the active catalytic site deep within a gorge-like fold of the protein.The aromatic gorge in the protein is approximately $20 \AA$ deep and penetrates halfway into the enzyme. The active site lies at the base of this gorge only $4 \AA$ Above the base, leading some to label this the active gorge. The aromatic gorge is a more appropriate term, though, because $40 \%$ of its lining is composed of 14 aromatic residuems located in the gorge which are highly conserved from different species of acetylcholinesterases (50). The high aromatic content of the walls and floor may explain why studies have proposed hydrophobic and anionic binding sites independent of the active site. Only a few acidic residues are present within the gorge. The aromatic residues clearly play an important role in the stabilization of the complex. Electrostatic as well as hydrophobic effects are of importance here (15). Electrostatic computations reveal the enzyme to be a single massive dipole. Electrostatic potential map of AChE suggests that this enzyme, possibly like other enzymes with charged substrates, steers its substrate toward its gorge and into the active site.

The most interesting aspect of this enzyme is the peripheral anionic site on its surface. A peripheral site was initially suggested by Changeux (21) to be involved in allo-

\footnotetext{
${ }^{1}$ Many Persian Gulf veterans returned from that war only to develop unexplained illnesses for which the causes remain elusive. Recently, a committee of the Institute of Medicine reported that they were unable to find an association between such illnesses and a number of chemical exposures in the Gulf, including pyridostigmine bromide (anti-nerve gas pills) and organophosphate pesticides, both of which act by blocking the acetylcholinesterase necessary for nerves and muscles to work properly. However, it is possible that relationships between anticholinesterases and unexplained illnesses were obscured by genetic variations in sensitivity to these compounds. Butyrylcholinesterase is a plasma protein that binds these anticholinesterases and prevents their actions on muscles and nerve.
} 
steric inhibition of the enzyme. The peripheral anionic site on $\mathrm{AChE}$, located at the active center gorge entry, encompasses overlapping binding sites for allosteric activators and inhibitors; yet, the molecular mechanisms coupling this site to the active center at the gorge base to modulate catalysis remain unclear. The peripheral site has also been proposed to be involved in heterologous protein associations occurring during synaptogenesis or upon neurodegeneration (17). Site-directed labeling and mutagenesis studies place the location of this peripheral anionic site at or near the rim of the aromatic gorge (10). This site has the ability to bind to many different types of ligands, and by doing so effects the conformation of the active center. Hence ligand association with this site may prevent access of substrates to the gorge by steric obstruction to restrict entry to the gorge, by charge repulsion imparted through the association of a cationic ligand, or by allosteric mechanism in which the active center conformation is altered. Several bis- and tris-quaternary ligands bind to the peripheral site, and bis-quaternary ligands with large interquaternary distances (cca $14 \AA$ ) prevent binding of both active center and peripheral site ligands. Six residues have established activity within this site: Trp 286, Tyr 72, Tyr 124, Glu 285, and Asp 74 and Tyr 341, which are located on the opposite side of the gorge entrance to the previous four. Residues Trp 286, Tyr 72 and Tyr 124 are critical for dictating specificity. Likewise do the residues Trp 86, Phe 337, Tyr 342 and Glu 202. Occupation of the peripheral site may affect the conformation of the active center and the configuration of bound ligands at the active center. The above mentioned domains are responsible for the selectivity of AChE for substrates and inhibitors. Specificity for acyl chain length and the discrimination for substrate activation or inhibition are governed largely by the two Phe's 295 and 297 whose side chains outline the acyl pocket (79).

The peripheral anionic site is involved in a „cross-talk“ mechanism with the active site. This mechanism is an interaction between the Trp 286 and Trp 86 residues. When Trp 286 is bonded on the periphery, it effects the Trp 86 in the active site and causes distinct conformations of the active site to occur, thus changing the functionality of the enzyme. Asp 74 also plays a role in allosteric modulation of the enzyme. This residue acts with Tyr 341, as well as other residues along the aromatic gorge, and terminates at Tyr 337. The sensitivity of these residues and the plasticity of the active center are probably the result of evolutionary design aimed to confer optimal catalytic activity under a wide variety of conditions that are characteristic for the operation of acetylcholinesterase in the synaptic cleft (79).

\subsubsection{Hydrolysis of acetylcholine}

The hydroxyl group on the serine executes a nucleophilic attack on an electrophilic carbon atom of the substrate, in this case the ester linkage between choline and the acyl group to temporarily form a covalent acyl bond between the enzyme and the substrate. The imidazole nitrogen of histi- dine may form a transient hydrogen bond with the hydroxyl group of the serine, promoting the nucleophilic reaction. The imidazole group may then facilitate the transfer of the acyl group from the serine hydroxyl to water. This is followed by a rapid hydrolysis of the acylated enzyme yielding acetic acid, and the restoration of the esteratic site. The pathway is similar to a pipeline, where substrate goes in one end and the products come out the other through conformational changes, along with the hydrophobic and electrostatic forces (104). Acetylcholine is the neurotransmitter common to many synapses throughout mammalian nervous systems. AChE is bound to cellular membrane of excitable tissues at cholinergic synaptic junctions, endoplasmic reticulum, among other membranes, which are usually associated with nerve impulse conduction. $\mathrm{AChE}$ is also found in red blood cells.

The optimum $\mathrm{pH}$ for $\mathrm{AChE}$ is 7.0 with the isoionic point near the $\mathrm{pH}$ of 5.35. The specificity at substrate concentrations of $1 \times 10-^{3} \mathrm{M}$ and constant enzyme level (approximately optimal for acetylcholine), produce the following relative rates of hydrolysis for several ester substrates: acetylcholine, 100; propionylcholine, 96; butyrylcholine, negligible; and triacetin, 11. A typical activator for AChE is 0.02 $\mathrm{M} \mathrm{Mg}^{2+}$, which is stimulatory in purified preparations.

\subsubsection{Substrate Inhibition}

Various explanations have been proposed to account for the different responses of AChE and BuChE to excess substrate. Rosenberry (92) suggested that the rate limiting step in catalysis was formation of an induced fit complex, and substrate inhibition was brought about by interference with this step. It has also been proposed that substrate inhibition is due to deacylation being retarded by binding of a second acetylcholine molecule to the anionic subsite of the acyl enzyme (59). The inhibition of AChE by excess of substrate is one of the key features that distinguishes it from BuChE. $\mathrm{BuChE}$ exhibits the converse substrate activation, and both phenomena are likely to be related to the binding of substrate, and to the catalytic mechanism of the enzymes. It is not known whether substrate inhibition has a biological role, or is simply a consequence of the structure and molecular mechanism of AChE action.

It has been suggested that AChE is allosterically regulated by the binding of acetylcholine to the peripheral site through conformational changes at the active centre (21). During development, the electrophoretic mobility and sedimentation coefficient of rat brain $\mathrm{G} 4 \mathrm{AChE}$ remain constant, but its kinetic parameters including substrate inhibition are changed (54). Amphiphilic AChE from mosquito showed no substrate inhibition when freshly extracted, however upon conversion to its non-amphiphilic derivatives, with thiocyanate (a chaotropic anion), the substrate inhibition returned (30). These results indicate that the environment may confer a slight conformational change in AChE, which results in substrate inhibition. The importance of the peripheral site in substrate inhibition has been 
supported by Radic et al. (89), based on studies of competition of substrate with the peripheral site ligand propidium.

\subsubsection{Molecular forms of AChE}

The enzyme in its natural state is a monomer with a molecular weight around 60,000 and often forms aggregates which continue to produce catalytic activity. The enzyme monomer is an alpha/beta protein that contains 537 amino acids with Asp1 as the N-terminal and Cys537 as the C-terminal.

Cholinesterases show a polymorphism of quaternary structures, of similar catalytic activity but differing in their hydrodynamic parameters and ionic or hydrophobic interactions. In the past the different polymorphic forms have been separated by sedimentation on density gradients, or by electrophoretic techniques, with or without detergent, which has led to a number of naming strategies. In this paper molecular forms are referred to using the recently agreed upon nomenclature of Massoulie (71).

Catalytic subunits, which may vary in glycosylation, can oligomerise into dimers or tetramers, giving rise to the globular (G) forms: G1, G2 and G4. The globular forms can further be divided depending on their amphiphilicity, due to the possibility of cell membrane attachment by either a glycophosphatidylinositol (GPI) anchor or the hydrophobic P subunit. Attachment of a collagen-like tail (Q subunits) to one, two or three catalytic tetramers gives the A4, A8 and A12 asymmetric forms which bind to the basal lamina. Free cysteine residues form inter-subunit disulphide bonds, to covalently dimerise catalytic subunits, and to attach catalytic subunits to $\mathrm{P}$ and $\mathrm{Q}$ polypeptide anchors. Tetramers are formed by electrostatic and hydrophobic interaction between two disulphide bonded dimers (40).

\section{Anticholinesterases}

For a long time the anticholinesterases of the most interest were the organophosphate and carbamate compounds employed as insecticides and nerve agents with military importace (1). Recently there are also inhibitors of AChE with practical use as therapeutics against Alzheimer's disease.

Although the catalytic triad of AChE is housed deep within the gorge, pharmacological observations demonstrate that AChE can be efficiently target by numerous inhibitors. Several regions in the complex structure of AChE can contribute to the overall picture of ligand afinity. These include all the protein domains through which the ligand proceeds to reach the active site in the bottom of gorge, such as the rim area surrounding the entering part of gorge and the amino acid residues lining its walls (104). In addition, the peripheral anionic site and/or the hydrophobic domains within the active site itself may be involved in ligand interactions. This heterogenity of potential sites might explain the existence of multiple inhibitors of AChE. In- hibition can be either reversible, by competitively blocking the substrate reaching the active site or quasi-irreversible, by covalent reaction with the active site serine, inactivating the catalytic ability of the enzyme.

Competitive inhibition takes place by blocking substrate at the active site (tacrine, edrophonium), non competitive inhibition occurs by binding to the peripheral site (propidium, gallamine).The bis-quaternary ligands as for example decamethonium or BW284c51 bind across both active and peripheral sites.

The longest known and most widely used inhibitor is the natural alkaloid physostigmine. This carbamoylates the active site serine residue, greatly slowing the acyl-enzyme hydrolysis reaction compared with the acetylated enzyme. Organophosphorus compounds such as diisopropyl fluorophosphate (DFP) are very potent inhibitors of AChE and they are used as agricultural insecticides or as nerve gases in chemical warfare. These compounds react with the active site serine forming a very stable covalent phosphoryl-enzyme complex. Carbamates and organophosphates are the most important groups of $\mathrm{AChE}$ inhibitors.

\subsection{Carbamates}

The longest known and the most widely used inhibitor of AChE is the natural alkaloid physostigmine (eserine). Physostigmine comes from the calabar bean (Physostigma venenosum) which grows in West Africa. The structure of physostigmine, first carbamate found in nature, was discovered by Stedman and Barger (105). When anticholinesterase activity of physostigmine was found and the meaning of $\mathrm{N}$-methyl carbamic group as essential moiety for biological activity was recovered, thousands of different carbamates were synthesized. With a few exceptions they are either $\mathrm{N}$-methyl or N,N-dimethyl carbamates. The Nmethyl carbamates predominate in number and importace. Some of them, mainly discharged and lipophilic carbamates found exercise as insecticides (carbaryl, moban, dimetan, isolan, and hundreds of others), another found exercise in human and veterinary medicine (miotine, pyridostigmine, syntostigmine, etc.). Some carbamates were very toxic also for mammals including human and about their use as chemical weapons was speculated ( $\mathrm{T}$ 1123) (85). Chemical structures of some important carbamates and carbamate pesticides are given in Fig. 1.

Carbamates act by carbamylating of AChE and abolishing its physiological function. The kinetic of AChE inhibition by carbamate can be illustrated by the Scheme 1 .

Enzyme acetylcholinesterase (E) and carbamate (CX) create intermediate complex (ECX) with dissociation constant $\mathrm{K}_{\mathrm{d}}$ which lose leaving group of carbamate $(\mathrm{X})$ and the result of this procerdure is carbamoylated enzyme (EC). This step of reaction is characterized by rate constant of carbamylation $\left(\mathrm{k}_{2}\right)$. The stability of carbamylated $\mathrm{AChE}(\mathrm{EC})$ is dependent on the character of carbamate. EC decarbamylated spontaneously by velocity characte- 
<smiles>COC(=O)Oc1ccc(N(C)C2CCN(C)C2C)cc1</smiles>

Physostigmine<smiles>CC(=O)Oc1cccc([N+](C)([O-])Br)c1</smiles>

Neostigmine bromide<smiles>CC(=O)Oc1cccc2c1CCS2</smiles>

Moban

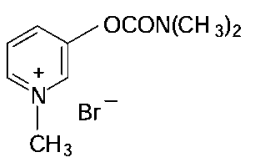

Pyridostigmine bromide<smiles>CCN(CC)c1cccc(OC(C)=O)c1</smiles>

T-1123<smiles>CCCc1cccc(OC(C)=O)c1OC(C)(C)C</smiles><smiles>CCOP(=S)(OCC)Oc1ccc([N+](=O)[O-])cc1</smiles>

Parathion

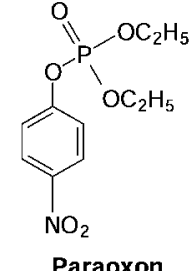<smiles>COP(=O)(O)ON1C(=O)NCC1CN(C)C</smiles><smiles>CCOP(=S)(OCC)Oc1cc(C)nc(C(C)C)n1</smiles>

Diazinon

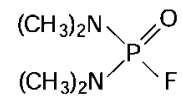

Dimefox
Pyrimicarb

Fig. 1: Chemical structures of some important carbamates and carbamate pesticides.

$$
\mathrm{E}+\mathrm{CX} \stackrel{K_{\mathrm{d}}}{\rightleftharpoons} \mathrm{ECX} \stackrel{k_{1}}{\longrightarrow} \mathrm{EC} \stackrel{k_{3}}{\longrightarrow} \mathrm{E}+\mathrm{C}
$$

Scheme 1.

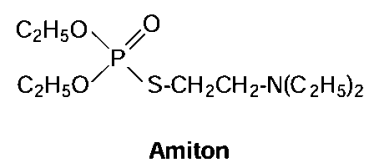

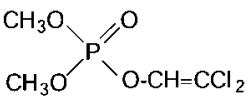

Dichlorvos

Fig. 2: Chemical structures of some organophosphates and organophosphate pesticides.

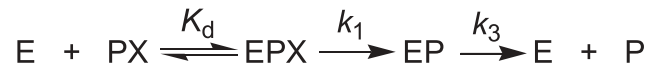

Scheme 2.

Tab. 2: Rates of spontaneous regeneration of carbamylated cholinesterases.

\begin{tabular}{|c|c|c|c|}
\hline Carbamyl Group & Cholinesterase & Half-life & Reference \\
\hline $\mathrm{CH}_{3} \mathrm{NH}-\mathrm{CO}-$ & AChE, eel & $38 \mathrm{~min}$ & $\mathrm{a}$ \\
\hline$\left(\mathrm{CH}_{3}\right)_{2} \mathrm{~N}-\mathrm{CO}-$ & AChE, eel & $27 \mathrm{~min}$ & $\mathrm{~b}$ \\
\hline$\left(\mathrm{CH}_{3}\right)_{2} \mathrm{~N}-\mathrm{CO}-$ & AChE, bovine & $56 \mathrm{~min}$ & $\mathrm{~b}$ \\
\hline$\left(\mathrm{CH}_{3}\right)_{2} \mathrm{~N}-\mathrm{CO}-$ & BuChE, human & $3-5 \mathrm{hr}$ & $\mathrm{b}$ \\
\hline
\end{tabular}

References: ${ }^{\mathrm{a}}$ Wilson et al., 1961, ${ }^{\mathrm{b}}$ Aldridge and Reiner, 1972

Tab. 3: Rates of spontaneous regeneration of phosphorylated cholinesterases.

\begin{tabular}{|c|c|c|c|}
\hline Phosphoryl Group & Cholinesterase & Half-life & References \\
\hline$\left(\mathrm{CH}_{3} \mathrm{O}\right)_{2}-\mathrm{P}(\mathrm{O})-$ & AChE, rat & $121 \mathrm{~min}$ & $\mathrm{a}$ \\
\hline$\left(\mathrm{CH}_{3} \mathrm{O}\right)_{2}-\mathrm{P}(\mathrm{O})-$ & AChE, rabbit & $82 \mathrm{~min}$ & $\mathrm{~b}$ \\
\hline$\left(\mathrm{C}_{2} \mathrm{H}_{5} \mathrm{O}\right)_{2}-\mathrm{P}(\mathrm{O})-$ & AChE, rat & $44 \mathrm{hr}$ & $\mathrm{a}$ \\
\hline$\left(\mathrm{C}_{2} \mathrm{H}_{5} \mathrm{O}\right)_{2}-\mathrm{P}(\mathrm{O})-$ & AChE, eel & 27 days & $\mathrm{c}$ \\
\hline$\left(\mathrm{C}_{2} \mathrm{H}_{5} \mathrm{O}\right)_{2}-\mathrm{P}(\mathrm{O})-$ & BuChE, human & 30 days & $\mathrm{d}$ \\
\hline$\left(\mathrm{C}_{2} \mathrm{H}_{5} \mathrm{O}\right)_{2}-\mathrm{P}(\mathrm{O})-$ & AChE, sheep & $48 \mathrm{hr}$ & $\mathrm{e}$ \\
\hline$\left(\mathrm{C}_{2} \mathrm{H}_{5} \mathrm{O}\right)_{2}-\mathrm{P}(\mathrm{O})-$ & AChE, hen & $2 \mathrm{hr}$ & $\mathrm{d}$ \\
\hline
\end{tabular}

${ }^{a}$ Vandekar and Heath (1957), ${ }^{\mathrm{b}}$ Aldridge (1953), ${ }^{\mathrm{c}}$ Wilson (1951), ${ }^{\mathrm{d}}$ Davison (1955), ${ }^{\mathrm{e}}$ Blaber and Creasey (1960) 
rized by a rate constant of decarbamylation $\left(\mathrm{k}_{3}\right)$. The half lives $\left(\mathrm{t}_{0.5}=\ln 2 / \mathrm{k}_{3}\right)$ of typical carbamylated AChEs are then, for example, between 20-60 min. It comes to this, that inhibition of $\mathrm{AChE}$ by carbamates has character of pseudoirreversible reaction. Rates of spontaneous regeneration of some carbamylated AChEs are summarized in Tab. 2.

\subsection{Organophosphates}

Organophosphates are typically synthetically prepared compounds. The only one organophosphate known in nature is anatoxin-a(s), toxic product of some cyanobacteria. All other toxic organophosphates were produced by human, either as pesticides or as nerve agents for warfare. First highly toxic organophosphates were prepared in Germany and Great Britain near before World War Two. Their extensive research and development come in fifth and sixth decade of the past century. The hazard problems which brought using of these compounds for environment and for mankind are known very well and there are not resolved comfortable.

Organophosphates react with AChE, likewise as carbamates, according to Scheme 2.

Acetylcholinesterase (E) creates with organophosphate (PX) intermediate complex (EPX) with dissociation constant $\mathrm{K}_{\mathrm{d}}$ which loses leaving group of organophosphate (X) and the result of this procedure is phosphorylated enzyme (EP). EP is mostly quite stable and its velocity of dephosphorylation, characterized by a rate constant of dephosphorylation $\left(\mathrm{k}_{3}\right)$, is very slow. The half lives $\left(\mathrm{t}_{0.5}=\ln 2 / \mathrm{k}_{3}\right)$ of typical phosphorylated AChEs range several hours till several days. It comes to this, that inhibition of AChEs by organophosphates is practically irreversible and dephosphorylation step of this reaction is negligible. Rates of spontaneous regeneration of some phosphorylated AChEs are summarized in Tab. 3 .

\subsubsection{Organophosphate pesticides}

Organophosphate pesticides were used in the fight with different pests in agriculture and forestry for a long time. A major objection to organophosphate pesticides has been their high mammalian toxicity and the resulting hazards associated with their use. While the objection is valid for what might be called the first generation of organophosphates (schradan, paraoxon, parathion), it does not hold to nearly the same extent for the second generation compounds (malathion, diazinon, fenitrothion) (72). Therefore many of them are used till this time. Chemical structures of some important organophosphates and organophosphate pesticides are given in Fig. 2.

\subsubsection{Organophosphate nerve agents}

Among lethal chemical weapons agents, the nerve agents have an entirely dominant role. Nerve agents acquired their name because they affect the transmission of
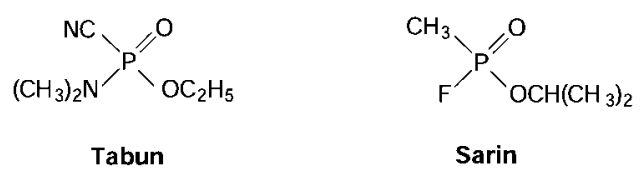<smiles>CC(C)OP(C)(=O)F</smiles><smiles>CCOP(C)(=O)SCCN(C(C)C)C(C)C</smiles>

Fig. 3: Chemical structures of some military important organophosphates.

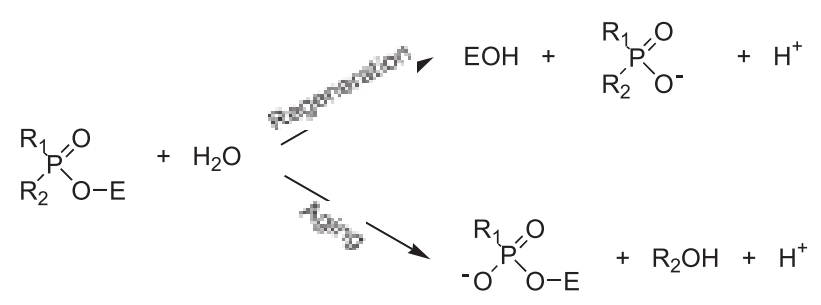

Scheme 3.

nerve impulses in the nervous system. All nerve agents belong chemically to the group of organo-phosphorus compounds. They are stable and highly toxic and have rapid effects both when absorbed through the skin and via respiration. It was not until the early 1930's that German chemists observed that organophosphorus compounds could be poisonous. In 1934, Dr Gerhard Schrader, a chemist at IG Farben, was given the task of developing a pesticide. Two years later a phosphorus compound with extremely high toxicity was produced for the first time. This phosphorus compound, given name tabun, was the first of the substances later referred to as nerve agents (57). Chemical structures of some important organophosphate nerve agents are given in Fig. 3.

\subsection{Spontaneous regeneration and aging}

Phosphorylated AChEs can undergo spontaneous hydrolysis to yield free enzyme $(34,109)$. The reaction follows first order kinetic with respect to [EP] because the concentration of water is relatively very high, and it remains constant. Spontaneous regeneration is a chemical reaction depending upon an enzyme, temperature, $\mathrm{pH}$ and ionic strength and namely on the kind of phosphoryl group (Tab. 3). A phosphorylated AChE may dephosphorylate and be regenerated, or it may dealkylate, in which case it is permanently inhibited and does not regenerate spontaneously or with reactivators.

The dealkylation of phosphorylated AChE is also known as aging. Like spontaneous regeneration, the rate of aging depends on the $\mathrm{AChE}$ in question and on the nature 
of the phosphoryl group. Also aging follows first-order kinetics. The aging half-time of the diethyl phosphoryl enzyme is $41 \mathrm{hr}$ compared with $4.6 \mathrm{hr}$ for the diisopropyl phosphoryl AChE (52). Some groups age with alarming speed. For example, the aging half-life of the phosphorylating group of the phosphonate nerve agent, soman, is only $6 \mathrm{~min}$ at $25^{\circ} \mathrm{C}$, pH 7.4 using bovine erytrocyte AChE. By substituting cyclohexyl for the 1,2,2-trimethylpropyl (pinacolyl) group of soman, the aging half-life increased to $4000 \mathrm{~min}$ or by 666 times (26). Clearly then the rate of aging is very dependent on the alkyl groups substituted on the phosphorus.

\subsection{Reactivators}

The idea that certain compounds might greatly accelerate spontaneous regeneration of phosphorylated $\mathrm{AChE}$ is connect with Wilson's (111) experiments with hydroxylamine and choline. The hydroxylamine pointed to the necessity of finding compounds with improved nucleophilic properties, while the choline indicated that quarternary nitrogen might amplify the nucleophilic attack (112). The therapeutic potential of such compounds stimulated a search which culminated with the discovery of pyridine-2-aldoxime methiodide (2-PAM) by Wilson and Ginsburg (112) and Childs et al. (23). At present time several hundreds of such compounds are known and these are named as reactivators
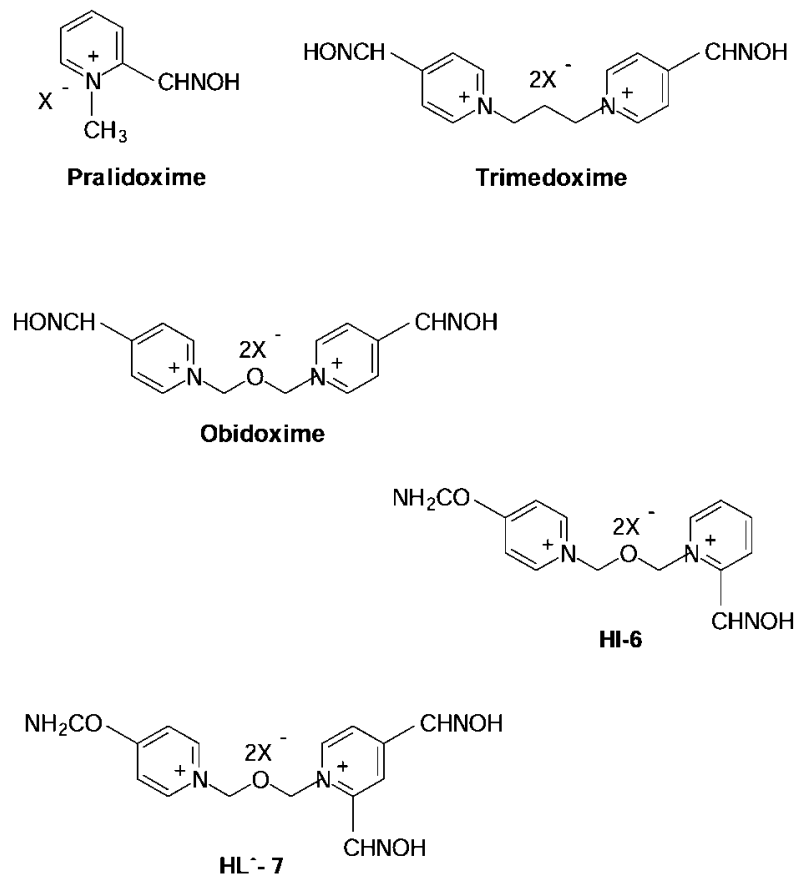

Fig. 4: Chemical structures of some pyridine oxime reactivators.

$$
\mathrm{EP}+\mathrm{R} \stackrel{K_{\mathrm{R}}}{\rightleftharpoons} \mathrm{EPR} \stackrel{k_{\mathrm{R}}}{\longrightarrow} \mathrm{E}+\mathrm{PR}
$$

Scheme 4. of phosporylated AChE (56). 2-PAM has become an informal standard against which the efficacy of other reactivators is measured. The best-known reactivators are aldoximes derived from pyridine, and some of them found exercise in human medicine as antidotes against organophosphate poisoning. There are mainly bis-quaternary dialdoximes (trimedoxime, obidoxime) and bisquaternary monoaldoximes (HI-6, Hlö7).Chemical structures of some important reactivators of phosphorylated $\mathrm{AChE}$ are given in Fig. 4.

The kinetic of reactivation is proceed according to the Scheme 4.

Phosphorylated enzyme (EP) create with reactivator (R) transient komplex (EPR). The product of this reaction is regenerated enzyme (E) and phosphorylated oxime (PR). That themselves are powerful inhibitors of $\mathrm{ChE}$, but they are unstable and decompose in a matter of minutes or hours (49).

\section{Nerve Agent Antidotes}

The effects of nerve agent exposure can be mitigated by the use of antidotes. Recent antidotes for nerve agent poisoning include administration of atropine together with reactivator of phosphorylated AChE (91). Atropine has been known for some time to be a competitive antagonist to muscarinic receptors and attenuates the effects of excess acetylcholine in the synaptic cleft. Atropine decreases secretions, reverses the spasms and contractions of smooth muscles and helps restore normal neurotransmission. Nevertheless, atropine is not able to restore AChE activity and its physiological function. This efficiency have only oxime reactivators. Reactivation of organophosphate-inhibited AChE by oximes is the primary reason for their effectiveness in the treatment of organophosphate poisoning (35).

\section{Nerve Agent Pyridostigmine Pretreatment (NAPP)}

The therapeutic agent pyridostigmine bromide has been used to treat myasthenia gravis, a chronic disease of neuromuscular transmission (78). Pyridostigmine is an AChE inhibitor in a manner analogous to organophosphorous agents with several important exceptions. The U. S. Army found that when given to animals in advance of nerve agent exposure, pyridostigmine has several beneficial effects. First, pyridostigmine reversibly carbamoylates the active site of AChE and does not significantly impair neuro-transmission. In addition, pyridostigmine is a competitive antagonist to phosphorylating agents and offers $\mathrm{AChE}$ a degree of protection against nerve agents. When animals are pretreated with pyridostigmine to a minimal level of carbamoylated AChE (20-40\% of available AChE) and then exposed to lethal doses of nerve agents, the animal spontaneously regenerates enough AChE to carry on vital func- 
tions. However, administration of atropine and 2-PAM chloride are still required when excess nerve agent remains to phosphorylate the AChE previously protected by pyridostigmine. Whereas NAPP affords protection against tabun and soman in animal models $(55,58)$, it provides little or no protection against sarin, GF, and VX exposure $(5,108)$.

\section{Alzheimer's disease and $\mathrm{AChE}$}

Alzheimer's Disease (AD) is a neurodegenerative disorder affecting mainly aging populations in industrialised nations. This civilization disease effects only in the United States more than 4 million people. AD is characterized by loss of memory and cognition and its etiology is unknown. Approximately $90 \%$ of the cases are classified as sporadic late onset. By age 85 one out of two people has AD. Clinical picture of $\mathrm{AD}$ is characterised by three major pathological signs: beta-amyloid plaques, neurofibrillary tangles, and synaptic loss (43). A deficiency in cholinergic neurotransmission is considered to be one of the major causes of memory impairments in patient $(13,31,107)$.

A role for the cholinergic system in human memory was suggested in the early 1970 s, by demonstrating that the cholinergic antagonist scopolamine impaired learning in man $(28,38)$. Whereas the AChE inhibitor physostigmine was found to increase long term memory processes (32). Around the same time it was discovered that post mortem AD brain tissue showed reduction in the cholinergic neuronal markers choline acetyltransferase and AChE (31) and the loss of $\mathrm{AChE}$ in $\mathrm{AD}$ has more recently been refined to selective loss of membrane bound G4 (97). All these findings led to the formulation of a „cholinergic hypothesis“, i.e. that AD is associated with an impairment in cholinergic transmission $(39,113)$, linking abnormalities in the cholinergic system to certain functional and pathological changes in AD $(18,88)$. Since then abnormalities have been found in other parts of the cholinergic system: ACh synthesis (102), choline uptake (95), and in some cases, muscarinic receptors (114).

The importance of AChE in AD was emphasised by Smith and Cuello (103), suggesting that different cell groups where lesions occur in AD share a common feature, they all contain AChE. Cholinesterases were also found in senile plaques (44), even at the initial stages of their formation (76), and in neurofibrillary tangles (75). Mesulam and coworkers have reported that $\mathrm{AChE}$ in plaques and tangles shows a lower $\mathrm{pH}$ optimum, a reduced sensitivity to the inhibitors BW284c51, tacrine, and physostigmine (75). The $\mathrm{AChE}$ plays important role in the ethiology, diagnostic and therapy of $\mathrm{AD}(84)$.

\subsection{AChE inhibitors as Alzheimer's disease drugs}

Current therapeutic strategies for the treatment of AD aim mainly to alleviate cognitive deficit by activating defective cholinergic transmission. Work has mainly centred on inhibitors of $\mathrm{AChE}$ who represent at present standard of care for the symptomatic treatment of mild to moderate Alzheimer's disease. Cholinesterase inhibitors are a class of compounds used as chemical weapons on the one hand and simultaneously as a class of drugs that have been used for a number of years to slow the progression of Alzheimer's disease (83). The idea behind them is based on the fact that in Alzheimer's, there is a lack of a acetylcholine in the brain that shows degenerative changes of neurons. A drug that inhibits ChE means that more acetylcholine is available to carry out nerve cell communications. First clinical experiments of Alzheimer's disease treatment were due largely with physostigmine $(14,24)$ but the first medicament used in clinical practice was tacrine (Cognex) $(33,80)$. Chemical structures of some other inhibitors of AChE tested as potential drugs of Alzheimer's disease are given in Fig. 5.

In short- and long-term studies, the three cholinesterase inhibitors most commonly used, donepezil, rivastigmine, and galantamine, have demonstrated efficacy in improving not only cognition but also function and behavior in patients suffering from mild to severe cases of Alzheimer's disease and other forms of dementia (25). However, the benefits of cholinesterase inhibitors in treating the broad spectrum of symptoms associated with Alzheimer's disease<smiles>COc1ccc2c3c1OC1CC(O)CCC31CCCN(C)C2</smiles>

Galantamine<smiles>Nc1c2c(nc3ccccc13)CCCC2</smiles>

Tacrine<smiles>COc1cc2c(cc1OC)C(=O)C(CC1CCN(Cc3ccccc3)CC1)C2</smiles>

Donepezil<smiles>CCN(C)C(=O)Oc1cccc(C(C)N(C)C)c1</smiles>

Fig. 5: Chemical structures of some acetylcholinesterase inhibitors used as Alzheimer's disease medicaments. 
are not sustained indefinitely, and the illness continues to progress even while patients are receiving treatment. Additionally, while temporary stabilization may occur, there is typically only a modest improvement from baseline, and side effects from treatment with ChE inhibitors can be too severe for some patients to tolerate. Therefore, additional therapies for Alzheimer's disease still need to be developed that include more tolerable agents with alternative mechanisms of action and broader efficacy (36). Recently, evidence was presented that AChE accelerates assembly of amyloid- $\beta$-peptides into the amyloid fibrils that form the senile plaques characteristic of $\mathrm{AD}$ (53). It was suggested that a hydrophobic environment close to the peripheral binding site of the enzyme, at or near the entrance to the active-site gorge, might be involved in this process $(48,90)$.

\section{References}

1. Aldridge WN, Reiner E. Enzyme Inhibitors as Substrates. Interaction of Esterases with Esters of Organophosphorus and Carbamic Acids. North Hollan Publ Comp, Amsterdam, 1972.

2. Aldridge WN. Serum esterases. 1. Two type sof esterase (A and B) hydrolysing p-nitrophenylacetate, propionate and butyrate, and a method for thein determination. Biochem J 1953;53:110-24.

3. Allderdice PW, Gardner HAR, Galutira D, Lockridge O, LaDu BN, McAlpine PJ. The cloned butyrylcholinesterase (BCHE) gene maps to a single chromosome site, 3q26. Genomics 1991;11:452-4.

4. Altland K. Goedde HW. Heterogeneity in the silent gene phenotype of pseudocholinesterase of human serum. Biochem Genet 1970;4:321-38.

5. Anderson DR, Harris LW, Woodard CL, Lennox WJ. The effect of pyridostig mine pretreatment on oxime efficacy against intoxication by soman or VX in rats. Drug Chem Toxicol 1992;15:285-94.

6. Arias HR.Topology of ligand binding sites on the nicotinic acetylcholine receptor. Brain Res Brain Res Rev 1997;25:133-91.

7. Arpagaus M, Kott M, Vatsis KP, Bartels CF, La Du BN, Lockridge O. Structure of the gene for human butyrylcholinesterase. Evidence for a single copy. Biochemistry 1990;29:124-31.

8. Ashani Y, Shapira S, Levy D, Wolfe AD, Doctor BP, Raveh L. Butyrylcholinesterase and acetylcholinesterase prophylaxis against soman poisoning in mice. Biochem Pharmacol 1991;41:37-41

9. Balasubramanian AS. Amyloid beta peptide processing, insulin degrading enzyme and butyrylcholinesterase. Neurochem Res 2001;26:453-6.

10. Barak D, Kronman C, Ordentlich A et al. Acetylcholinesterase peripheral anionic site degeneracy conferred by amino seid arrays sharing a common core J Biol Chemistry 1994;269:6296-305.

11. Barnard EA. Enzymatic destruction of acetylcholine. In Hubbard JI (ed.): The Peripheral Nervous System, New York, USA: Plenum Press, 1974;201-24.

12. Barta C, Sasvari-Szekely M, Devai A, Kovacs E, Staub M, Enyedi P. Analysis of mutations in the plasma cholinesterase gene of patients with a history of prolonged neuromuscular block during anesthesia. Mol Genet Metab 2001;74 484-8.

13. Bartus RT, Dean RL, Beer B, Lippa AS. The cholinergic hypothesis of geriatric memory dysfunction. Science 1982;217:408-14.

14. Becker R, Giacobini E, Elble R, McIlhany M, Sherman K. Potential pharmacotherapy of Alzheimer's disease. A comparison of various forms of physostigmine administration. Acta Neurol Scand Suppl 1988;116:19-32.

15. Berman HA, Leonard K. Ligand exclusion on acetylcholinesterase. Biochemistry 1990;29:10640-9.

16. Boeck AT, Fry DL, Sastre A, Lockridge O. Naturally occurring mutation, Asp70his, in human butyrylcholinesterase. Ann Clin Biochem 2002;39:154-6.

17. Bourne Y, Taylor P, Radic Z, Marchot P. Structural insights into ligand interactions at the acetylcholinesterase peripheral anionic site. EMBO J 2003;22: 1-12.

18. Bowen DM, Allen SJ, Benton JS et al. Biochemical assessment of serotonergic and cholinergic dysfunction and cerebral atrophy in Alzheimer's disease. J Neurochem 1983;41:266-72.

19. Brown DA. Neurotoxins and the ganglionic (C6) type of nicotinic receptor. Adv Cytopharmacol 1979;3:225-30.

20. Carmona GN, Jufer RA, Goldberg SR et al. Butyrylcholinesterase accelerates cocaine metabolism: in vitro and in vivo effects in nonhuman primates and hu- mans. Drug Metab Dispos 2000;28:367-71.

21. Changeux JP. Responses of acetylcholinesterase from Torpedo marmorata to salts and curarizing drugs. Mol Pharmacol 1966;2:369-92.

22. Chen Z, White MM. Forskolin modulates acetylcholine receptor gating by interacting with the small extracellular loop between the M2 and M3 transmembrane domains. Cell Mol Neurobiol 2000;20:569-77.

23. Childs AF, Davies DR, Green AL, Rutland JP. The reactivation by oximes and hydroxamic acids of cholinesterase inhibited by organo-phosphorus compounds. Br J Pharmac 1955;10:462-5.

24. Coelho F, Birks J. Physostigmine for Alzheimer's disease. Cochrane Database Syst Rev 2001;2:CD001499.

25. Corey-Bloom J. Galantamine: a review of its use in Alzheimer's disease and vascular dementia. Int J Clin Pract 2003;57:219-23.

26. Coult DB, Marsh DJ, Read G. Dealkylation studies on inhibited acetylcholinesterase. Biochem J 1956;98:869-73.

27. Court JA, Martin-Ruiz C, Graham A, Perry E. Nicotinic receptors in human brain: topography and pathology. J Chem Neuroanat 2000;20:281-98.

28. Crow TJ, Grove-White IG. An analysis of the learning deficit following hyoscine administration to man. Brit J Pharmacol 1973;49:322-7.

29. Darvesh S, Grantham DL, Hopkins DA. Distribution of butyrylcholinesterase in the human amygdala and hippocampal formation. J Comp Neurol 1998; 393:374-90.

30. Dary O, Wedding RT. Absence of substrate inhibition and freezing-inactivation of the mosquito acetylcholinesterase are caused by alterations of hydrophobic interactions. Biochim Biophys Acta 1990;1039:103-9.

31. Davies P, Maloney AJ. Selective loss of central cholinergic neurons in Alzheimer's disease. Lancet 1976;2:1403.

32. Davis KL, Mohs RC, Tinklenberg JR, Pfefferbaum A, Hollister LE, Kopell BS Physostigmine: improvement of long-term memory processes in normal humans. Science. 1978;201:272-4

33. Davis KL, Powchik P. Tacrine. Lancet 1995;345:625-30

34. Davison AN. Return of cholinesterase activity in the rat after inhibition by organophosphorus compounds. Biochem J 1955;60:339-46.

35. Dawson RM. Review of oximes available for treatment of nerve agent poisoning. J Appl Toxicol 1994;14:317-31.

36. Doody RS. Current treatments for Alzheimer's disease: cholinesterase inhibitors. J Clin Psychiatry 2003;64(Suppl 9):11-7.

37. Doutin D, Brodeur J. An automated method for simultaneous determination of serum pseudocholinesterase activity, dibucaine number and fluoride number. Clin Biochem 1970;3:245-54.

38. Drachman DA, Leavitt J. Human memory and the cholinergic system. Arch Neurol 1974;30:113-21.

39. Dunnett SB, Fibiger HC. Role of forebrain cholinergic systems in learning and memory: relevance to the cognitive deficits of aging and Alzheimer's dementia. Prog Brain Res 1993;98:413-20.

40. Duval N, Krejci E, Grassi J, Coussen F, Massoulie J, Bon S. Molecular architecture of acetylcholinesterase collagen-tailed forms; construction of a glycolipid-tailed tetramer. EMBO J. 1992;11:3255-61.

41. Earl CJ, Thompson RHS. Cholinesterase levels in the nervous system in triortho-cresyl phosphate poisoning. Br J Pharmacol 1952;7:685-94.

42. Eglen RM, Hegde SS, Watson N. Muscarinic receptor subtypes and smooth muscle function. Pharmacol Rev 1996;48:531-65.

43. Fine RE. The biochemistry of Alzheimer disease. Alzheimer Dis Assoc Disord 1999;13(Suppl 1):S82-7.

44. Friede RL. Enzyme histochemistry of neuroglia. Prog Brain Res 1965;15:35-47.

45. Galenko-Yaroshevskii AP, Derlugov LP, Ponomarev VV, Dukhanin AS. Pharmacokinetics and pharmacodynamics of a new local anesthetic agent. Bull Exp Biol Med 2003;136:170-3.

46. Gaughan G, Park H, Priddle J, Craig I, Craig S. Refinement of the localization of human butyrylcholinesterase to chromosome 3q26.1-q26.2 using a PCR-derived probe. Genomics 1991;11:455-8.

47. Geula C, Mesulam MM. Cholinesterases and the pathology of Alzheimer disease Alzheimer Dis Assoc Disord 1995;9(Suppl. 2):23-8.

48. Giacobini E. Cholinergic function and Alzheimer's disease. Int J Geriatr Psychiatry. 2003;18(Suppl 1):S1-S5.

49. Hackley BE, Jr, Steinberg GM, Lamb JC. Formation of potent inhibitors of $\mathrm{AChE}$ by reaction of pyridinaldoximes with isopropyl methylphosphonofluoridate (GB). Arch Biochem 1959;80:211-4.

50. Harel M, Schalk I, Ehret-Sabatier L et al. Quaternary ligand binding to aromatic residues in the active-site gorge of acetylcholinesterase. Proc Natl Acad Sci USA 1993;90:9031-5.

51. Hirota SA. A quick guide to muscarinic acetylcholine receptors. BioPharm J 2001;5:6-8.

52. Hobbiger FW. Chemical reactivation of phosphorylated human and bovine true cholinesterase. Br J Pharmac 1956;11:295-303. 
53. Inestrosa NC, Alvarez A, Perez CA et al. Acetylcholinesteraseaccelerates assembly of amyloid-beta-peptides into Alzheimer's fibrils:possible role of the peripheral site of the enzyme. Neuron 1996;16:881-91.

54. Inestrosa NC, Ruiz G. Membrane-bound form of acetylcholinesterase activated during postnatal development of the rat somatosensory cortex. Dev Neurosci 1985;7:120-32.

55. Kassa J, Krejčová G, Samnaliev I. A comparison of the neuroprotective efficacy of pharmacological pretreatment and antidotal treatment in soman-poisoned rats. Acta Med (Hradec Králové) 2003;46:101-7.

56. Kassa J. Review of oximes in the antidotal treatment of poisoning by organophosphorus nerve agents. J Toxicol 2002;40:803-16.

57. Khurana D, Prabhakar S. Organophosphorus intoxication. Arch Neurol 2000; $57: 600-2$.

58. Krejčová G, Kassa J. Neuroprotective efficacy of pharmacological pretreatment and antidotal treatment in tabun-poisoned rats. Toxicology 2003;185:129-39.

59. Krupka RM. The mechanism of action of acetylcholinesterase: substrate inhibition and the binding of inhibitors. Biochemistry 1963;2:76-82.

60. Kutty KM, Payne RH. Serum pseudocholinesterase and very-low-density lipoprotein metabolism. J Clin Lab Anal 1994;8:247-50.

61. Layer PG, Willbold E. Novel functions of cholinesterases in development, physiology and disease. Prog Histochem Cytochem 1995;29:1-94.

62. Leff P, Scaramellini C, Law C, McKechnie K. A three-state receptor model of agonist action. Trends Pharmacol Sci 1997;18:355-62.

63. Lehmann DJ, Johnston C, Smith AD. Synergy between the genes for butyrylcholinesterase $\mathrm{K}$ variant and apolipoprotein $\mathrm{E} 4$ in late-onset confirmed Alz heimer's disease. Hum Molec Genet 1997;6:1933-6.

64. Le Novere N, Corringer P-J, Changeux J-P. The diversity of subunit composition in nAChRs: evolutionary origins, physiologic and pharmacologic consequences. J Neurobiol 2002;53:447-56.

65. Lockridge O, Adkins S, La Du BN. Location of disulfide bonds within the sequence of human serum cholinesterase. J Biol Chem 1987;262:12945-52.

66. Lockridge O, Bartels CF, Vaughan TA, Wong CK, Norton SE, Johnson LL. Complete amino acid sequence of human serum cholinesterase. J Biol Chem 1987;262:549-57.

67. Lustig LR, Peng $\mathrm{H}$. Chromosome location and characterization of the human nicotinic acetylcholine subunit alpha (alpha) 9 (CHRNA9) gene. Cytogenet Genome Res 2002;98:154-9.

68. Main A, Soucie W, Buxton I, Arinc E. The Purification of Cholinesterase from Horse Serum. Biochem J 1974;143:733-44.

69. Masson P, Froment MT, Fortier PL, Visicchio JE, Bartels CF, Lockridge O Butyrylcholinesterase-catalysed hydrolysis of aspirin, a negatively charged ester and aspirin-related neutral esters. Biochim Biophys Acta 1998;1387:41-52.

70. Massoulie J, Sussman J, Bon S, Silman I. Structure and functions of acetylcholinesterase and butyrylcholinesterase. Prog Brain Res 1993;98:139-46.

71. Massoulie J. The origin of the molecular diversity and functional anchoring of cholinesterases. Neurosignals 2002;11:130-43.

72. Matsumura F.: Toxicology of Insecticides. Plenum Press, New York 1975.

73. Matzke SM, Oubre JL, Caranto GR, Gentry MK, Galbicka G. Behavioral and immunological effects of exogenous butyrylcholinesterase in rhesus monkeys. Pharmacol Biochem Behav 1999;62:523-30.

74. McIlroy SP, Crawford VLS, Dynan KB, McGleenon BM, Vahidassr MD Lawson JT, Passmore AP. Butyrylcholinesterase K variant is genetically associated with late onset Alzheimer's disease in Northern Ireland. J Med Genet 2000;37:182-5.

75. Mesulam MM, Geula C, Moran MA. Anatomy of cholinesterase inhibition in Alzheimer's disease: effect of physostigmine and tetrahydroaminoacridine on plaques and tangles. Ann Neurol 1987;22:683-91.

76. Moran MA, Mufson EJ, Gomez-Ramos P. Colocalization of cholinesterases with beta amyloid protein in aged and Alzheimer's brains. Acta Neuropathol (Berl). 1993;85:362-9

77. Morgan AA. Apnoea following suxamethonium: the genetic study of four generations of a family. J Med Genet 1982;19:22-5.

78. Newsom-Davis J. Therapy in myasthenia gravis and Lambert-Eaton myasthenic syndrome. Semin Neurol 2003;23:191-8

79. Ordentlich A, Barak D, Kronman C, et al. Dissection of the human acetylcholinesterase active center determinants of substrate specificity. Identification of residues constituting the anionic site, the hydrophobic site, and the acyl pocket. J Biol Chem 1993;268:17083-95.

80. Ott BR. Medical treatment of Alzheimer's disease: past, present, and future Med Health R I 2002;85:210-2.

81. Palacios JM, Boddeke HW, Pombo-Villar E. Cholinergic neuropharmacology: an update. Acta Psychiatr Scand Suppl 1991;366:27-33

82. Paterson D, Nordberg A.Neuronal nicotinic receptors in the human brain. Prog Neurobiol 2000;61:75-111.

83. Patočka J. Acetylcholinesterase inhibitors - From nervous gas to Alzheimer's disease therapeutics. Chem Listy 1998;92:1016-9.
84. Patočka J, Strunecká A, Řípová D: Cholinesterázy a jejich význam v etiologii, diagnostice a terapii Alzheimerovy nemoci. Čs Fyziol 2001;50:4-10.

85. Patočka J.: T-1123, highly toxic carbamate with military significance (In Bulgarian). Voenno Med Delo 1990;44:14-19.

86. Paton WD, Zaimis E. The methonium. Pharmacol Rev 1952;4:219-53

87. Perry EK, Perry RH, Blessed G, Tomlinson BE. Changes in brain cholinesterases in senile dementia of Alzheimer type. Neuropathol Appl Neurobiol 1978; 4:273-7.

88. Perry EK. The cholinergic system in old age and Alzheimer's disease. Age Ageing 1980;9:1-8.

89. Radic Z, Reiner E, Taylor P. Role of the peripheral anionic site on acetylcholinesterase: inhibition by substrates and coumarin derivatives. Mol Pharmacol 1991;39:98-104.

90. Reyes AE, Perez DR, Alvarez A et al. A monoclonal antibody against acetylcholinesterase inhibits the formation of amyloid fibrils induced by the enzyme. Biochem Biophys Res Commun 1997;232:652-5.

91. Ricordel I, Meunier J. Chemical weapons: antidotes. View about the real means, perspectives. (in French) Ann Pharm Fr 2000;58:5-12.

92. Rosenberry TL. Catalysis by acetylcholinesterase: evidence that the rate-limiting step for acylation with certain substrates precedes general acid-base catalysis. Proc Natl Acad Sci USA 1975;72:3834-8.

93. Rubboli F, Court JA, Sala C, Morris C, Chini B, Perry E, Clementi F. Distribution of nicotinic receptors in the human hippocampus and thalamus. Eur J Neurosci. 1994:6:1596-604.

94. Rubinstein HM, Lubrano T, La Du BN. DNA mutation associated with the human butyrylcholinesterase K-variant and its linkage to the atypical variant mutation and other polymorphic sites. Am J Hum Genet 1992;50:1086-103.

95. Rylett RJ, Ball MJ, Colhoun EH. Evidence for high affinity choline transport in synaptosomes prepared from hippocampus and neocortex of patients with Alzheimer's disease. Brain Res 1983;289:169-75.

96. Scarpero HM, Dmochowski RR. Muscarinic receptors: what we know. Curr Urol Rep. 2003;4:421-8.

97. Schegg KM, Harrington LS, Neilsen S, Zweig RM, Peacock JH. Soluble and membrane-bound forms of brain acetylcholinesterase in Alzheimer's disease. Neurobiol Aging 1992:13:697-704.

98. Schneider F, Steenland K, Hernandez B, Wilson B, Krieger R, Spencer J, Margetich S. Monitoring peach harvest workers exposed to azinphosmethyl residues in Sutter County, California, 1991. Environ Health Perspect 1994;102: $580-5$.

99. Schumacher M, Camp S, Maulet Y, Newton M, MacPhee-Quigley K, Taylor SS, Friedmann T, Taylor P.Primary structure of Torpedo californica acetylcholinesterase deduced from its cDNA sequence. Nature. 1986;319:407-9.

100. Schwarz M, Glick D, Loewenstein Y, Soreq H. Engineering of human cholinesterases explains and predicts diverse consequences of administration of various drugs and poisons. Pharmacol Ther 1995; 67: 283-322.

101. Shen WX, Jobling P, Horn JP. The sensitivity of nicotinic synapses in bullfrog sympathetic ganglia to alpha-bungarotoxin and neuronal-bungarotoxin. $\mathrm{Br}$ J Pharmacol 1994;113:898-902.

102. Sims NR, Bowen DM, Allen SJ, Smith CC, Neary D, Thomas DJ, Davison AN Presynaptic cholinergic dysfunction in patients with dementia. J Neurochem 1983;40:503-9.

103. Smith AD, Cuello AC. Alzheimer's disease and acetylcholinesterase-containing neurons. Lancet 1984;1:513.

104. Soreq H, Gnatt A, Loewenstein Y, Seville LF. Excavations into the active-site gorge of acetylcholinesterase. TIBS 1992;17:353-8.

105. Stedman E, Barger G. Physostigmine (eserine). Part III. J Chem Soc 1925; 127:247-58.

106. Sussman JL, Harel M, Frolow F et al. Atomic structure of acetylcholinesterase from Torpedo californica: a prototypic acetylcholine-binding protein. Science 1991;253:872-9.

107. Terry RD, Masliah E, Salmon DP et al. Physical basis of cognitive alterations in Alzheimer's disease: synapse loss is the major correlate of cognitive impairment. Ann Neurol 1991;30:572-80.

108. Tuovinen K, Kaliste-Korhonen E, Raushel FM, Hanninen O.Success of pyridostigmine, physostigmine, eptastigmine and phosphotriesterase treatments in acute sarin intoxication. Toxicology 1999;134:169-78

109. Vandekar M, Heath DF. The reactivation of cholinesterase after inhibition in vivo by some dimethyl phosphate esters. Biochem J 1957;67:202-8.

110. Volpicelli LA, Levey AI. Muscarinic acetylcholine receptor subtypes in cerebral cortex and hippocampus. Prog Brain Res 2004;145:59-66.

111. Wilson IB. Acetylcholinesterases. XI. Reversibility of tetraethylpyrophosphate inhibition. J Biol Chem 1951:190:111-7.

112. Wilson IB, Ginsburg S. Reactivation of acetylcholinesterase inhibited by alkylphosphates. Arch Biochem Biophys 1955;54:269-71.

113. Weinstock M. Possible role of the cholinergic system and disease models. J Neural Transm Suppl. 1997;49:93-102. 
114. Whitehouse PJ, Au KS. Cholinergic receptors in aging and Alzheimer's disease Prog Neuropsychopharmacol Biol Psychiatry 1986;10:665-76.

115. Wright CI, Geula C, Mesulam MM. Neuroglial cholinesterases in the norma brain and in Alzheimer's disease: relationship to plaques, tangles, and patterns of selective vulnerability. Ann Neurol 1993;34:373-84.

Submitted April 2004

Accepted July 2004.

Prof. RNDr. Jiř́ Patočka, DrSc., Purkyně Military Medical Academy, Department of Toxicology, 50001 Hradec Králové,

Czech Republic.

e-mail: patocka@pmfhk.cz 